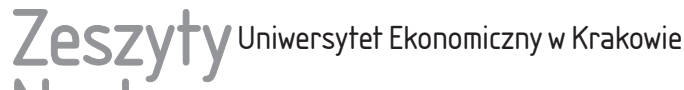 Naukowe
}

\section{Ceny ziemi rolnej w Polsce na tle Unii Europejskiej}

\section{Streszczenie}

Ceny ziemi rolnej do momentu przystąpienia Polski do Unii Europejskiej były przedmiotem zainteresowania nie tylko potencjalnych inwestorów w sektorze rolno-spożywczym, ale także spekulantów, co spowodowało konieczność ich monitorowania również przez ekonomistów zajmujących się nauką o agroekonomii. Celem artykułu była próba oceny zachodzących zmian w cenach ziemi rolnej w Polsce na tle Unii Europejskiej oraz określenie zmiennych mogących mieć silny wpływ na kształtujący się średni poziom cen gruntów rolnych w krajach należących do Wspólnoty. Na podstawie badań dowiedziono, że występuje zróżnicowanie regionalne pod względem zmienności oraz wysokości cen gruntów rolnych w Unii Europejskiej. Wykazano również, że istnieje istotna zależność pomiędzy poziomem cen gruntów rolnych a wartością dopłat bezpośrednich oraz wartością produktu krajowego brutto per capita.

Słowa kluczowe: rynek ziemi, zmiany cen gruntów rolnych, determinanty cen, zróżnicowanie cen.

Klasyfikacja JEL: C19, Q15, R10.

Krzysztof Firlej, Uniwersytet Ekonomiczny w Krakowie, Wydział Ekonomii i Stosunków Międzynarodowych, Katedra Strategii Zarządzania i Rozwoju Organizacji, ul. Rakowicka 27, 31-510 Kraków, e-mail: krzysztof.firlej@uek.krakow.pl

Sebastian Kubala, Uniwersytet Ekonomiczny w Krakowie, Wydział Ekonomii i Stosunków Międzynarodowych, Katedra Strategii Zarządzania i Rozwoju Organizacji, ul. Rakowicka 27, 31-510 Kraków, e-mail: sebastian.kubala@uek.krakow.pl 


\section{Wprowadzenie}

Jak zaznaczył w swoich opracowaniach J. Bański (1998, s. 7-8): „Badania nad użytkowaniem ziemi rozpoczęto na początku XXI w. i były to na ogół opracowania map prezentujących sposób zagospodarowania ziemi na danym terytorium. Znacznie później pojawiły się publikacje tekstowe poświęcone szerokiej problematyce z zakresu użytkowania ziemi; począwszy od metod badań po analizę struktury użytkowania ziemi”; publikacje takie pojawiają się do dzisiaj. W życiu gospodarczym kraju ziemia stanowi bowiem bardzo istotny element jest podstawą zachodzących procesów produkcyjnych i jednym z najważniejszych czynników kształtujących potencjał produkcyjny. Ziemia jest uznawana za jeden z trzech (obok pracy i kapitału) czynników biorących udział w każdym zachodzącym procesie produkcyjnym (Ekonomika rolnictwa ... 1983).

Czynnik ziemi uznawany jest za zasób, który nie może zostać zastąpiony innym czynnikiem (nie jest substytucyjny), jest nieprzemieszczalny i w dużym zakresie jest czynnikiem niezniszczalnym (Firlej 2008). Zasób ten pełni wiele funkcji społeczno-ekonomicznych poprzez zaspokajanie rosnących potrzeb społeczeństwa. Pomimo że obserwuje się znaczne przekształcenia dotyczące celów ziemi rolnej na skutek postępującej globalizacji, przejawiającej się rozwojem gospodarczym, postępem technicznym oraz przemianami społecznymi, znaczenie ziemi rolnej w dalszym ciągu jest bardzo istotne, przede wszystkim pod względem bezpieczeństwa żywnościowego czy też równowagi ekologicznej (Wielofunkcyjność rolnictwa... 2010).

Wpływ na rynek ziemi rolnej mają w coraz większym stopniu uwarunkowania międzynarodowe. Postępująca globalizacja sprzyja rozwojowi gospodarek, co pośrednio wpływa na sposób wykorzystywania ziemi rolnej i poziom jej ceny. Proces transakcji gruntami rolnymi stanowi naturalny efekt rozwoju społeczno-gospodarczego. Z ekonomicznego punktu widzenia jeśli dane dobro podlega transakcji, posiada ono swoją cenę. Cena stanowi wyznacznik zdolności do pełnienia przez grunt funkcji źródła przyszłych korzyści uwidocznionych poprzez uzyskiwane dochody. Wielu autorów badało znaczenie różnych czynników wpływających na ceny gruntów, takich jak: osiągany dochód z gospodarstwa rolnego (Alston 1986), urbanizacja (Bell i Irwin 2004, Wu 2001), wielkość subwencji rządowych (Weersink i in. 1999), rodzaj terenu (Feichtinger i Salhofer 2013) czy też zmiany strukturalne w rolnictwie (Pyykkönen 2005). W polskiej literaturze również dokonywano rozróżnienia czynników determinujących poziom cen (Kucharska-Stasiak 2006, Pietrzykowski 2011). W badaniach wskazywano, że cena ziemi rolnej jest pośrednio uzależniona od wielu czynników, wśród których wyróżniamy uwarunkowania: ekonomiczne, historyczne, jakościowe, administracyjno-polityczne, prawne i społeczne. 
Zaprezentowane determinanty wpływają w różnej mierze na poziom wartości i cen gruntów. Pomimo że istnieje wiele bodźców wykazujących silne powiązania z wartością gruntów rolnych, to ich badanie jest mocno skomplikowane. Trudności te wynikają z faktu, że cena ziemi kształtowana jest poprzez wiele zróżnicowanych czynników, co przekłada się na brak uniwersalnego kryterium uzależniającego poziom ceny od określanej zmiennej. Można jednakże wydzielić pewne czynniki, które będą w podobnym stopniu wpływały na większość rynków gruntów rolnych, a także te, które będą doprowadzały do różnicowania regionalnego.

Celem artykułu była próba oceny zachodzących zmian w cenach ziemi rolnej w Polsce na tle Unii Europejskiej oraz określenie zmiennych mogących mieć duży wpływ na kształtujący się poziom cen gruntów rolnych w krajach należących do Wspólnoty. Zbadano następujące zmienne: wartość produkcji przemysłu rolnego, wielkość dotacji bezpośrednich oraz produkt krajowy brutto per capita. W pracy starano się zweryfikować hipotezę, że w większości krajów Unii Europejskiej istnieje silna zależność pomiędzy poziomem cen gruntów rolnych a rozwojem gospodarczym, produktywnością rolnictwa oraz wielkością otrzymywanych benefitów, przy występującym jednocześnie zróżnicowaniu regionalnym pod względem zmienności oraz wysokości cen gruntów rolnych we Wspólnocie. W tym celu wykorzystano metody analizy statystycznej i porównawczej. Dla określenia zależności pomiędzy cenami gruntów rolnych a wybranymi zmiennymi w krajach Unii Europejskiej bazowano na współczynniku korelacji liniowej Pearsona. Ponadto dokonano próby budowy modelu mającego na celu ukazanie zależności kształtowania się cen gruntów rolnych w krajach Unii Europejskiej pod wpływem wartości: produkcji przemysłu rolnego, dotacji bezpośrednich oraz produktu krajowego brutto per capita.

Do badań empirycznych wykorzystano dane pochodzące z bazy Eurostat, Banku Światowego oraz upublicznionych raportów i opracowań państwowych urzędów statystycznych.

\section{Wyniki badan}

W latach 2005-2015 w krajach Unii Europejskiej wystąpiły bardzo wyraźne zmiany, duża była również dynamika zmian poziomu cen gruntów rolnych (tabela 1).

Z danych zaprezentowanych $w$ tabeli 1 wynika, że w latach 2005-2015 nastąpił wzrost średniej ceny ziemi rolnej w Unii Europejskiej o 24,37\%. Największą dynamikę wzrostu tych cen odnotowały głównie państwa wstępujące wówczas do struktur unijnych. Akcesja stała się szansą osiągnięcia dochodów przez gospodarstwa rolne. Od momentu wstąpienia do Wspólnoty 


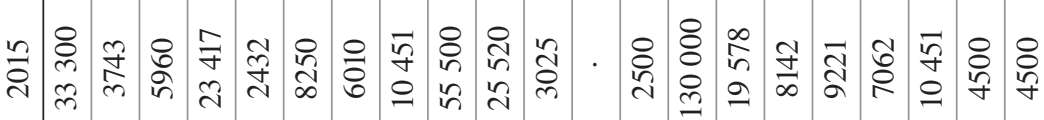

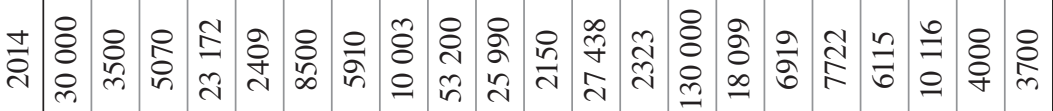

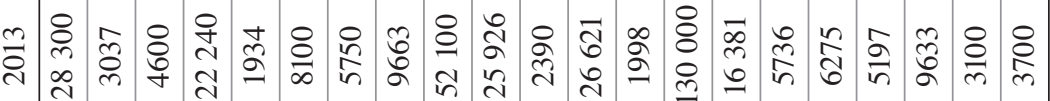

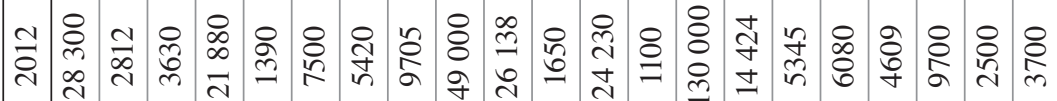

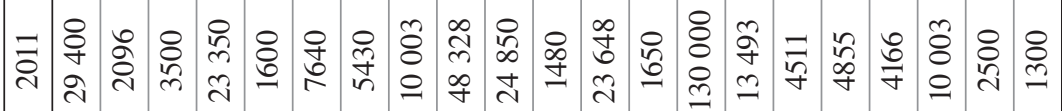

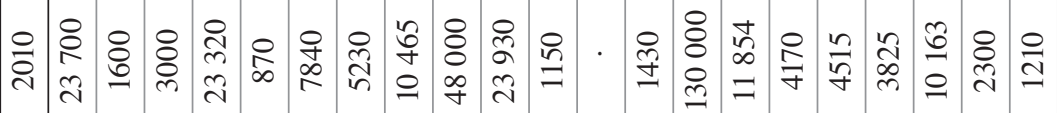

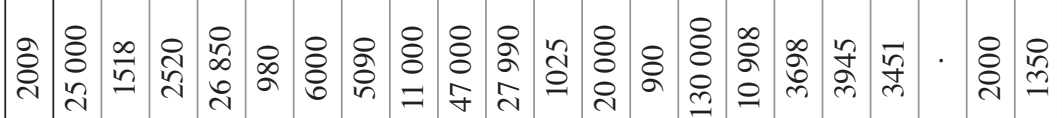

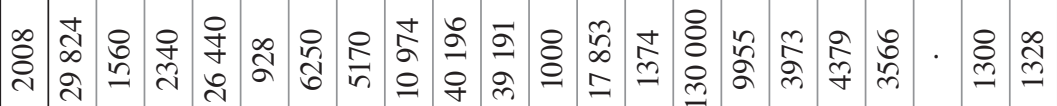

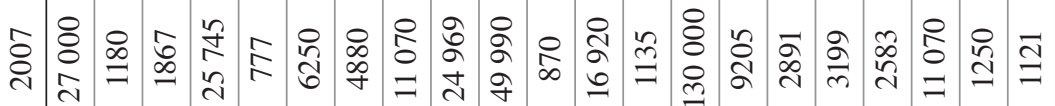

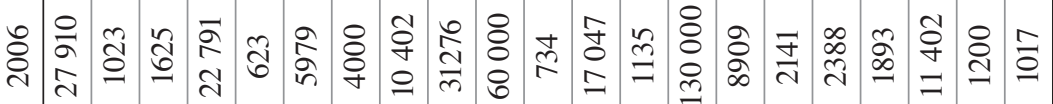

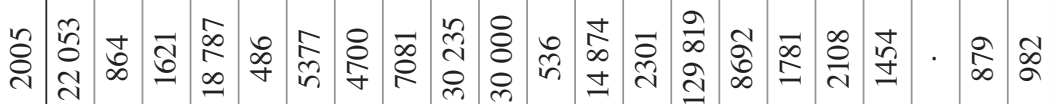
己 总

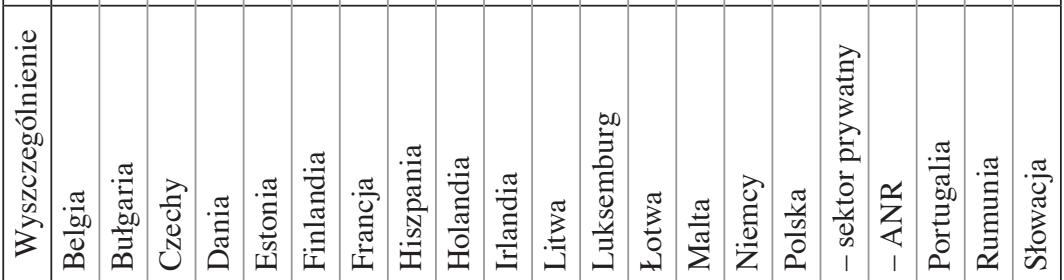




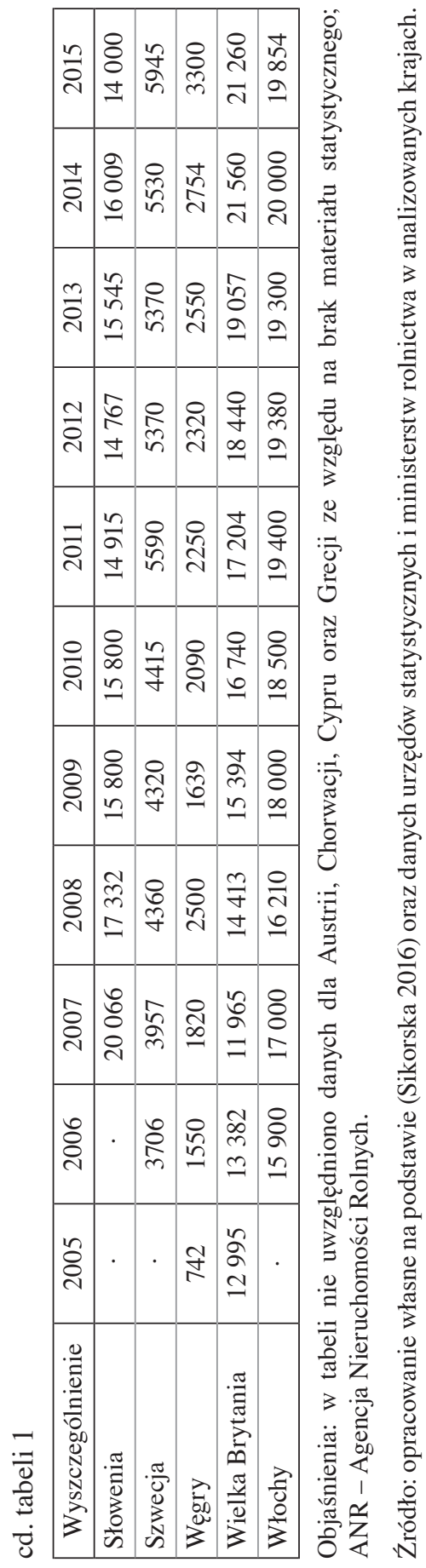


poszczególnych krajów ceny ziemi rolnej uległy zmianie - w przypadku krajów przystępujących do UE w 2004 r. (za wyjątkiem Słowenii) ceny te wzrosły średnio o 314,72\%, a w przypadku państw przystępujących do UE w 2007 r. średnio o 472,58\%. Portugalia, Irlandia i Słowenia należą do krajów odnotowujących spadek wartości cen gruntów rolnych (wartości te spadły w przypadku Portugalii o 8,34\% między 2015 i 2006 r., w przypadku Irlandii o 14,93\% między 2015 i 2005 r., w przypadku Słowenii o 30,23\% między 2015 i 2007 r.). W Irlandii spadek cen ziemi rolnej spowodowany był głównie zmniejszeniem nakładów na inwestycje po wcześniejszym przejściu gospodarki w stan recesji, w Portugalii spadek ten związany był z dystrybucją ziemi rolnej po obniżonych cenach w ramach aukcji niezagospodarowanych terenów.

W krajach Unii Europejskiej zauważono wyraźne zróżnicowanie regionalne w wysokości cen ziemi rolnej. Zaproponowano więc ich podział na cztery grupy:

- rejony o najwyższym obserwowanym poziomie cen, powyżej średniej unijnej - rejony Malty, Luksemburga, Beneluksu, Irlandii, Danii oraz Półwyspu Apenińskiego (średnia dla tych rejonów z wyłączeniem Malty': 27796 euro/ha),

- rejony o wysokich poziomach cen, oscylujące w granicach średniej unijnej rejony Wysp Brytyjskich, Półwyspu Iberyjskiego, Niemiec oraz Słowenii (średnia dla tych rejonów: 13173 euro/ha),

- rejony o umiarkowanym poziomie cen - rejony Skandynawii, Francji, Polski i Czech (średnia dla tych rejonów: 4977 euro/ha),

- rejony o najniższych poziomach cen, ze znaczną dynamiką wzrostową rejony krajów postsowieckich (Estonia, Litwa, Łotwa), Rumunii i Bułgarii oraz Słowacji i Węgier (średnia dla tych rejonów: 1872 euro/ha).

Równocześnie można zaobserwować jednoroczne spadki cen w niektórych państwach członkowskich UE (głównie w 2009 i 2012 r. - odpowiednio 10 i 11 przypadków). Do głównych czynników determinujących zachodzące zjawisko zaliczyć należy w przypadku niektórych krajów Europy Środkowo-Wschodniej restytucję, a w przypadku krajów o ugruntowanym stopniu rozwoju gospodarczego trwający kryzys globalny i postępujący spadek popytu na nieruchomości gruntowe.

Uwarunkowania światowe znalazły również odzwierciedlenie w sytuacji na krajowym rynku gruntów rolnych. Ceny gruntów rolnych w Polsce na tle Unii Europejskiej kształtują się na poziomie bliższym krajom należącym do regionu Europy Środkowo-Wschodniej. Pod względem średniej wartości cen ziemi rolnej Polska zajmuje 15. miejsce w całej Unii Europejskiej (polskie ceny są niższe od średniej unijnej o 12095 euro/ha). Ponadto w latach 2005-2015 w Polsce wystąpiły wyraźne wahania poziomu cen gruntów rolnych oraz ich dynamiki (rys. 2).

\footnotetext{
${ }^{1}$ Nie uwzględniono Malty ze względu na zbyt dużą dysproporcję cenową.
} 


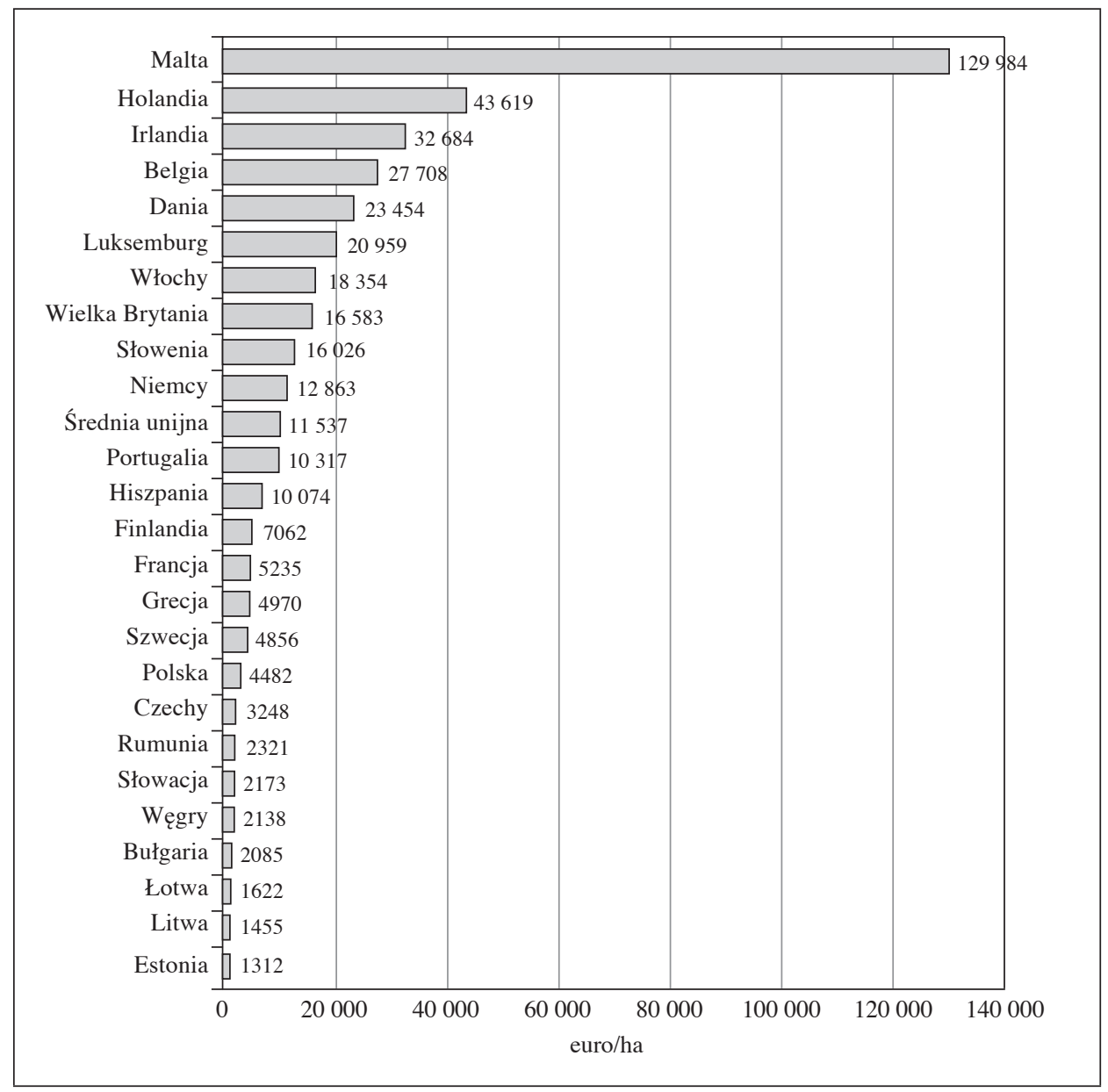

Rys. 1. Przeciętna cena gruntów rolnych w krajach Unii Europejskiej w okresie 2005-2015 (euro/ha)

Źródło: opracowanie własne na podstawie danych podanych w tabeli 1.

W pierwszych czterech latach okresu poakcesyjnego w Polsce odnotowano rosnący trend cen kształtujący się na poziomie 30-38\% (oprócz 2006 r., w którym odnotowany został wzrost w sektorze prywatnym o $13 \% \mathrm{w}$ stosunku do 2005 r.). Kolejny rok (2009) to okres, w którym ceny spadły względem cen z roku poprzedniego o $10 \%$ w sektorze prywatnym, zaś w przypadku obrotu ziem będących własnością Zasobu Własności Rolnej Skarbu Państwa o 5\%, by następnie stopniowo poziom cen z roku na rok się podnosił. W latach 2005-2016 ceny gruntów rolnych w Polsce wzrosły 4,57-krotnie. Średnie ceny gruntów w obrocie prywatnym w całym analizowanym okresie były wyższe niż ceny uzyskiwane 
w wyniku sprzedaży przez ANR o 25,11\%. Analiza zmian cen gruntów rolnych w Polsce wskazuje na niezmienny trend wzrostowy od 2005 do 2015 r. (z wyjątkiem 2009 r.).

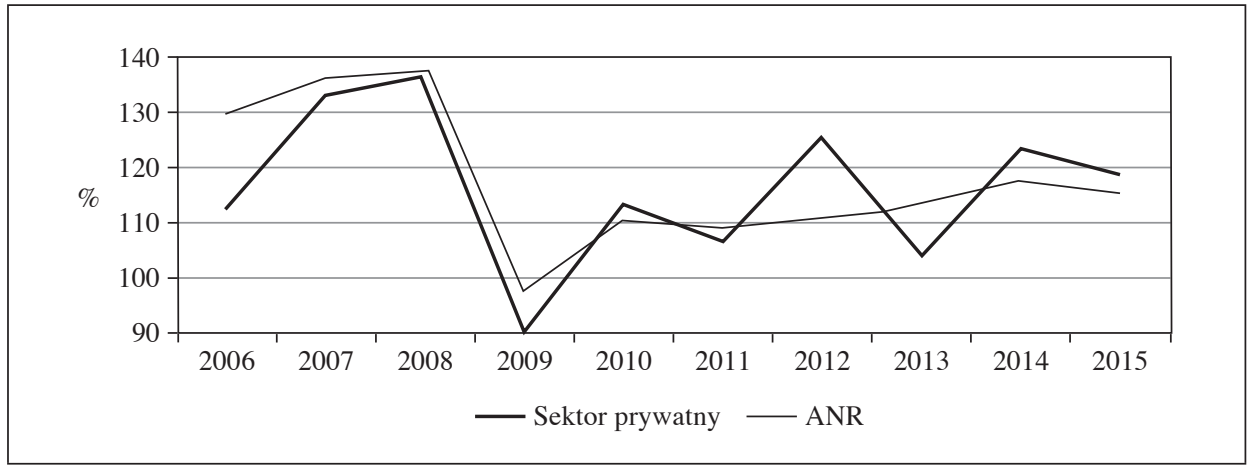

Rys. 2. Dynamika cen gruntów rolnych w sektorze prywatnym oraz będących własnością Zasobu Własności Rolnej Skarbu Państwa w Polsce w latach 2006-2015 $($ rok poprzedni $=100 \%)$

Źródło: opracowanie własne na podstawie danych podanych w tabeli 1.

Akcesja Polski do Unii Europejskiej spowodowała zwiększenie aktywności transakcyjnych na rynku gruntów rolnych oraz związane z tym zjawiskiem dostosowania cenowe (Chmieliński i in. 2009). Aktywność ta została jednak zahamowana przez kryzys gospodarczy. Gospodarka w Polsce mimo odporności na pojawiające się negatywne zjawiska finansowe nie była w stanie uniknąć spowolnienia wynikającego również ze wzrostu kosztów finansowania zewnętrznego, co skutkowało m.in. spadkiem liczby transakcji gruntami rolnymi oraz spadkiem wzrostu cen do 2010 r. (Żelazowski 2014). Po okresie względnej stagnacji w latach 2011-2014 nastąpiło znaczne zwiększenie liczby transakcji, w szczególności kontraktów zawieranych przez osoby fizyczne (rys. 3).

W ramach prowadzonych badań podjęto także próbę zidentyfikowania czynników mających wpływ na kształtowanie się poziomu cen gruntów rolnych oraz ich zróżnicowanie. W obliczeniach uwzględniono najistotniejsze zmienne określone na podstawie literatury przedmiotu. Wśród najważniejszych czynników wyróżniono:

- wartość produkcji przemysłu rolnego - zmienna ta odzwierciedla faktyczne rozmiary produkcji rolnej. Umożliwia ustalenie potencjału produkcyjnego danego obszaru, którego wzrost jest silnie skorelowany z poziomem cen;

- wartość dopłat bezpośrednich - są one niezwykle istotnym bodźcem kształtującym poziom cen gruntów rolnych i mają za zadanie zwiększać atrakcyjność rolnictwa uznawanego za jeden z głównych sektorów produkcyjnych. To podsta- 
wowe narzędzia Wspólnej Polityki Rolnej, których celem jest dążenie do wsparcia producentów rolnych zgodnie z zasadami zrównoważonego rozwoju;

- produkt krajowy brutto per capita - to miernik koniunktury gospodarczej. Ziemia podobnie jak źródła kapitałowe jest istotnym elementem procesu inwestycyjnego w rolnictwie, na którego wielkość ma wpływ globalna koniunktura. Analiza wykazała, że w przypadku dobrej koniunktury ceny ziemi rolnej wzrastają znacznie szybciej niż w fazach spadkowych.

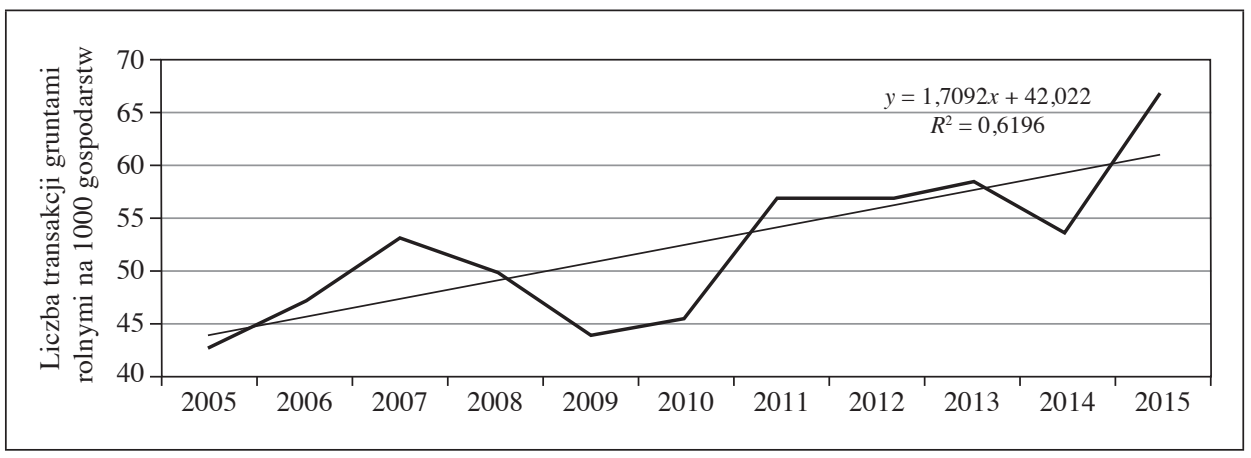

Rys. 3. Transakcje kupna-sprzedaży gruntów rolnych w Polsce w latach 2005-2015 Źródło: opracowanie własne na podstawie (Sikorska 2016).

Poziom korelacji pomiędzy średnim poziomem cen gruntów rolnych w krajach Unii Europejskiej w poszczególnych latach a powyższymi zmiennymi (tabela 2) wskazuje na silne powiązania. Największy poziom korelacji istnieje pomiędzy średnim poziomem cen gruntów rolnych oraz średnią wartością produkcji przemysłu rolnego.

Tabela 2. Zależność pomiędzy średnim poziomem cen gruntów rolnych a analizowanymi zmiennymi wyznaczona za pomocą korelacji liniowej Pearsona

\begin{tabular}{|l|c|}
\hline \multicolumn{1}{|c|}{ Zależność } & Wartość korelacji \\
\hline $\begin{array}{l}\text { Średni poziom cen gruntów rolnych, średnia wartość produkcji } \\
\text { przemysłu rolnego }\end{array}$ & 0,844907 \\
\hline $\begin{array}{l}\text { Średni poziom cen gruntów rolnych, średnia wartość dopłat } \\
\text { bezpośrednich }\end{array}$ & 0,677146 \\
\hline $\begin{array}{l}\text { Średni poziom cen gruntów rolnych, średnia wartość produktu } \\
\text { krajowego brutto per capita }\end{array}$ & 0,630687 \\
\hline
\end{tabular}

Źródło: opracowanie własne.

W pierwszym etapie kwantyfikacji zachodzących relacji pomiędzy wielkością cen gruntów rolnych krajów Unii Europejskiej a określonymi zmiennymi 
ze względu na panelowy charakter danych rozważano możliwości zastosowania jednego z trzech typów estymatorów: panelowego MNK, estymatora fixed effects oraz estymatora random effects ${ }^{2}$. Wyboru dokonano za pomocą porównania własności opisanych estymatorów, poprzez przeprowadzenie analizy testów heteroskedastyczności: testu Walda, testu Breuscha-Pagana oraz testu Hausmana.

Tabela 3. Wyniki estymowanej funkcji modelu

\begin{tabular}{|l|c|c|c|c|}
\hline \multicolumn{1}{|c|}{ Wyszczególnienie } & $\alpha_{0}$ & $\alpha_{1}$ & $\alpha_{2}$ & $\alpha_{3}$ \\
\hline Współczynniki & $-8,082$ & 0,085 & 0,217 & 1,336 \\
\hline $\begin{array}{l}\text { Błąd standardowy } \\
\text { współczynnika }\end{array}$ & 2,111 & 0,105 & 0,093 & 0,219 \\
\hline$Z$ & $-3,829$ & 0,8078 & 2,348 & 6,090 \\
\hline $\begin{array}{l}\text { Współczynnik } \\
\text { determinacji }\left(R^{2}\right)\end{array}$ & \multicolumn{3}{|c|}{0,671} \\
\hline Błąd standardowy reszt & \multicolumn{3}{|c|}{0,686} \\
\hline Funkcja linearyzowana & $\ln (Y)=-8,082+(0,085) \cdot \ln \left(X_{1}\right)+(0,217) \cdot \ln \left(X_{2}\right)+(1,336) \cdot \ln \left(X_{3}\right)$ \\
\hline Funkcja potęgowa & \multicolumn{3}{|c|}{$Y=0,003 \cdot X_{1}^{0,085} \cdot X_{2}^{0,217} \cdot X_{3}^{1,336}$} \\
\hline
\end{tabular}

Objaśnienie: z analizy wyłączono Maltę ze względu na znaczne odchylenia od wartości średniej ceny gruntów rolnych.

Źródło: opracowanie własne.

Na podstawie przeprowadzonego testu Walda stwierdzono zróżnicowanie wyrazów wolnych z jednoczesnym brakiem jednorodności poszczególnych obiektów, co sprawia, że właściwsze staje się zastosowanie modelu o ustalonych efektach (fixed effects). Na podstawie testu Breuscha-Pagana uznano natomiast, że wariancja składnika losowego efektów indywidualnych jest zróżnicowana dla poszczególnych obiektów, stąd właściwsze jest używanie estymatora random effects. Stosowanie modelu o losowych efektach potwierdził również test Hausmana. $\mathrm{Z}$ tego względu do badania relacji pomiędzy cenami gruntów rolnych w krajach Unii Europejskiej a wartością produkcji przemysłu rolnego, wartością dopłat bezpośrednich oraz wartością produktu krajowego brutto per capita użyto modelu o losowych efektach (random effects). W związku z niesatysfakcjonującymi rezultatami osiągniętymi z wykorzystaniem danych wyjściowych postanowiono jednak poddać je transformacji poprzez logarytmowanie, wobec czego ostatecznie oszacowany model przybrał postać potęgową:

$$
Y=\alpha_{0} \cdot X_{1}^{\alpha 1} \cdot X_{2}^{\alpha 2} \cdot \mathrm{X}_{3}^{\alpha 3},
$$

\footnotetext{
${ }^{2}$ Więcej na ten temat w pracy (Ekonometria współczesna... 2007).
} 
gdzie:

$Y$ - cena gruntów rolnych,

$X_{1}$ - wartość produkcji przemysłu rolnego,

$X_{2}$ - wartość dopłat bezpośrednich,

$X_{3}$ - produkt krajowy brutto per capita.

Oszacowany model obrazuje badane zjawiska w stopniu dobrym, może więc stanowić podstawę do prawidłowego wnioskowania o analizowanych zależnościach. Wpływ na to mają wartości współczynnika determinacji $R^{2}$, który informuje, że oszacowany model wyjaśnia zmienność zmiennej objaśnianej w 68,6\%. Ze względu na to, że przyjęty model ma postać potęgową, oszacowane parametry są interpretowane jako elastyczności. Zmienne objaśniające dany model wskazują na dodatni wpływ na zmienną objaśnianą. Wartości parametrów świadczą o tym, że wzrost wartości produkcji przemysłu rolnego o $1 \%$ powoduje wzrost cen gruntów rolnych o $0,09 \%$, wzrost wartości dopłat bezpośrednich o $1 \%$ skutkuje wzrostem cen gruntów rolnych o $0,22 \%$, zaś wzrost produktu krajowego brutto per capita o $1 \%$ jest czynnikiem powodującym wzrost cen gruntów rolnych o 1,34\%. W omawianych wynikach postawiono założenie niezmienionych wielkości pozostałych czynników. Po przyjęciu poziomu istotności $\alpha=0,05$ testy istotności parametrów strukturalnych wskazują na statystyczną istotność parametru $\alpha_{2}$ oraz $\alpha_{3}$, co oznacza, że zmienne objaśniające będące wartością dopłat bezpośrednich oraz wartością produktu krajowego brutto per capita mają istotny wpływ na zmienną objaśnianą (poziom cen gruntów rolnych). Testy istotności parametru strukturalnego $\alpha_{1}$ wykazały, że parametr ten nie jest statystycznie istotny.

\section{Podsumowanie}

Badania zaprezentowane w niniejszym artykule miały na celu ukazanie wpływu wybranych czynników na poziom cen ziemi rolnej w krajach UE. Przeprowadzone badania empiryczne miały także pomóc w określeniu zmian zachodzących w cenach ziemi rolnej w Polsce i Unii Europejskiej, pokazać ich regionalne zróżnicowanie oraz wskazać czynniki warunkujące ich poziom. Na podstawie tych badań skonstruowano następujące wnioski:

1. Analiza zmian cen gruntów rolnych w Polsce wskazuje na niezmienny trend wzrostowy w latach 2005-2015 (z wyjątkiem 2009 r.), przy czym ceny gruntów rolnych w obrocie prywatnym są wyższe niż ceny uzyskiwane w wyniku sprzedaży przez ANR. Poziom cen gruntów rolnych w Polsce jest znacznie niższy od średniej unijnej. 
2. Występuje wyraźne zróżnicowanie regionalne w wysokości cen ziemi rolnej w poszczególnych krajach Unii Europejskiej. Można dokonać podziału na cztery obszary różnicujące te ceny pod względem wielkości oraz dynamiki.

3. Przystąpienie danego kraju do Unii Europejskiej z jednej strony staje się szansą osiągnięcia dochodów przez gospodarstwa rolne, z drugiej powoduje zwiększenie aktywności transakcyjnych na rynku gruntów rolnych oraz staje się bodźcem prowzrostowym cen gruntów rolnych, w tym również w Polsce.

4. Ceny gruntów rolnych są wrażliwe na występujące wahania koniunkturalne, co skutkuje jednorocznymi spadkami cen w większości państw członkowskich w sytuacji pogorszającej się sytuacji gospodarczej.

5. Przeprowadzone badania pozwalają stwierdzić, że istotny wpływ na poziom cen gruntów rolnych ma wielkość otrzymywanych benefitów oraz wartość produktu krajowego brutto per capita. Zaproponowany przez autorów model określa czynniki kształtujące poziom cen gruntów rolnych zmiennymi wyjaśniającymi na poziomie 0,671 .

\section{Literatura}

Alston J.M. (1986), An Analysis of Growth of U.S. Farmland Prices, „American Journal of Agricultural Economics", vol. 68, nr 1, https://doi.org/10.2307/1241644.

Bański J. (1998), Gospodarka ziemia w Polsce w okresie restrukturyzacji, Polska Akademia Nauk, Instytut Geografii i Przestrzennego Zagospodarowania im. Stanisława Leszczyckiego, Warszawa.

Bell K.P., Irwin E.G. (2002), Spatially explicit Micro-level Modelling of Land Use Change at the Rural-Urban Interface, ,Agricultural Economics”, vol. 27, nr 3, https:// doi.org/10.1111/j.15740862.2002.tb00118x.

Chmieliński P., Goraj L., Karwat-Woźniak B., Kowalski A., Sikorska A. (2009), Instrumenty oddziaływania Państwa na kształtowanie struktury obszarowej gospodarstw rolnych w Polsce: rola systemu ubezpieczenia społecznego rolników w kształtowaniu tej struktury. Stan obecny i rekomendacje na przyszłość oraz propozycje nowych rozwiąań dotyczacych tego obszaru dla systemu ubezpieczeń rolników, ekspertyza dla Ministerstwa Rolnictwa i Rozwoju Wsi, IERiGŻ PIB, Warszawa.

Ekonometria współczesna (2007), red. M. Osińska, TNOiK „Dom Organizatora”, Toruń. Ekonomika rolnictwa. Zarys teorii (1983), red. A. Woś, F. Tomczak, PWRiL, Warszawa.

Feichtinger P., Salhofer K. (2013), What Do We Know about the Influence of Agricultural Support on Agricultural Land Prices?, „Journal of International Agricultural Trade and Development", vol. 62, nr 2.

Firlej K. (2008), Rozwój przemysłu rolno-spożywczego w sektorze agrobiznesu i jego determinanty, Wydawnictwo Uniwersytetu Ekonomicznego w Krakowie, Kraków.

Kucharska-Stasiak E. (2006), Nieruchomość w gospodarce rynkowej, Wydawnictwo Naukowe PWN, Warszawa.

Pietrzykowski R. (2011), Kształtowanie się cen ziemi rolniczej ze względu na wybrane czynniki użytkowo-rynkowe, ,Zeszyty Naukowe SGGW w Warszawie. Problemy Rolnictwa Światowego", t. 11(26), $\mathrm{nr} 4$. 
Pyykkönen P. (2005), Spatial Analysis of Factors Affecting Finnish Farmland Prices, the 99th seminar of the EAAE, Copenhagen.

Sikorska A. (2016), Rynek ziemi rolniczej-stan i perspektywy, Raporty Rynkowe, nr 19, IERiGŻ PIB, Warszawa.

Weersink A., Clark S., Turvey C.G., Sarker R. (1999), The Effect of Agricultural Policy on Farmland Values, ,Land Economics”, vol. 75, nr 3, https://doi.org/10.2307/3147188.

Wielofunkcyjność rolnictwa. Kierunki badań, podstawy metodologiczne i implikacje praktyczne (2010), red. J. Wilkin, IRWiR PAN, Warszawa.

Wu J.J. (2001), Environmental Amenities and the Spatial Patterns of Urban Sprawl, „American Journal of Agricultural Economics”, vol. 83, nr 3, https://doi.org/ 10.1111/0002-9092.00192.

Żelazowski K. (2014), Regionalne zróżnicowanie cen gruntów rolnych w Polsce, ,Zeszyty Naukowe Uniwersytetu Szczecińskiego. Studia i Prace Wydziału Nauk Ekonomicznych i Zarządzania", nr 36, t. 1.

\section{Prices of Agricultural Land in Poland against the Background of the European Union}

(Abstract)

Long before Poland's accession to the European Union, the prices of agricultural land were of interest not only to potential investors in the agri-food sector, but also to speculators, whom agroeconomists were tasked with monitoring. The aim of this study was to assess changes in agricultural land prices in Poland compared to the European Union and to identify variables that strongly depend on the average level of prices of agricultural land in the European Union. This article also demonstrates that in EU countries there is a significant correlation between agricultural land prices and the value of direct payments and the value of gross domestic product per capita.

Keywords: land market, changes in agricultural land prices, price differentation, price determinants. 